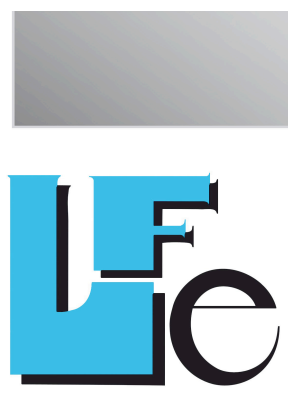

Revista de Lenguas para Fines

Específicos

\section{Revista de lenguas} para fines específicos

\author{
elSSN: 2340-8561
}

Journal information, indexing and abstracting details, archives, and instructions for submissions:

https://ojsspdc.ulpgc.es/ojs/index.php/LFE/index

\section{The implementation of effective dual-language programs}

\section{Barbara Muszynska \\ $M^{\text {a }}$ Elena Gómez Parra}

Universidad de Córdoba, Facultad de Educación, Av. San Alberto Magno, s/n. 18071, Córdoba (Spain).

Article first published online: 25 November 2015.

Article published online with DOI added: 5 April 2016. 


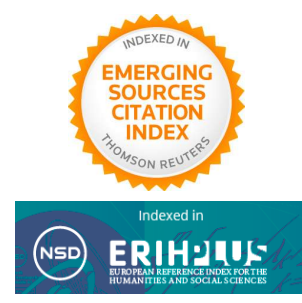

\title{
The implementation of effective dual-language programs
}

\author{
Barbara Muszynska \\ Ma Elena Gómez Parra $^{1}$
}

Universidad de Córdoba, Spain

\begin{abstract}
This research investigates the ways of implementing dual-language programs and the schools' internal procedures of evaluating them. Previous studies have examined the effectiveness of bilingual programs (Genovesee et al. 2005; Howard et al. 2005; Krashen 2004). However, there is little still known about schools' procedures that systematize the organizational aspect of such programs. The Mixed Methods Research (MMR) approach was applied in this study to analyze data collected through questionnaires, interviews, and case studies. The results of the study were combined and interpreted together. They bore out that the schools that have not introduced an effective internal evaluation system need institutional support in the form of practical publications / guides, referring to the organization of such programs, as well as in-house teacher and management training. There are often no forms of such training or resources available. This calls for improvement.
\end{abstract}

Keywords: Evaluation, implementation, dual-language education programs, MMR

\section{RESUMEN}

Este estudio investiga las formas de implementación de programas en dos lenguas y los procedimientos internos de las escuelas para evaluarlos. Estudios previos han examinado la eficacia de programas bilingües (Genovesee et al. 2005; Howard et al. 2005; Krashen 2004). Sin embargo, aún conocemos poco sobre los procedimientos que sistematizan los aspectos organizativos de tales programas. Hemos utilizado la Investigación de Métodos Mixtos (IMM) en este estudio para analizar los datos provenientes de cuestionarios,

1 Corresponding author - Universidad de Córdoba, Facultad de Educación, Av. San Alberto Magno, s/n. 18071, Córdoba (Spain).

Email: ff1gopam@uco.es 
entrevistas y estudios de caso. Los resultados se combinaron e interpretaron juntos, y ellos nos dicen que las escuelas que aún no han introducido un sistema interno de evaluación eficaz necesitan apoyo institucional en forma de publicaciones prácticas / guías, referidas a las organización de tales programas, así como profesorado interno y formación en dirección escolar. Esta formación no se encuentra fácilmente en el repositorio de recursos disponible, lo cual nos hace pensar que es uno de los puntos de mejora para el proceso.

Palabras clave: evaluación, implementación, programas de educación bilingüe, Investigación de Métodos Mixtos (IMM)

\section{INTRODUCTION}

There is a great variety of bilingual education programs and curricula which cover educational aims, the time of introducing the second language, the subjects taught in L1 and L2, and the percentage of time spent on both. Bilingual curricula, language allocation, language arrangements, translanguaging, and literacy are all essential factors that contribute to a bilingual education program's success. Van de Craen (2009) also believes that bilingual education helps to enhance cognitive abilities in all children and leads students to successful academic achievement and sociocultural integration. Nevertheless, it is not an easy task to establish all the factors that need to be considered in a bilingual education program, as teachers, students, and communities' needs differ depending on their individual context. What can be determined, however, are the conditions that are taken into account when implementing the programs and the ways in which their effectiveness is measured; after all, school principals use certain frameworks and benchmarks to assess their schools' programs.

There is a large volume of research concerning bilingual education and bilingual education programs, but comparatively very few studies that are concerned with and attempt to systematize the organizational aspects of the implementation of a bilingual program, hence the need for this research. Evaluations of the effectiveness of bilingual schools and recent reviews indicate the relative success of such programs (Cazabon et al., 1993; Genesee et al., 2005; Howard et al., 2005; Krashen, 2004; Lindholm-Leary, 2001). Brisk (2010), Mehisto (2012), and the European Commission (2010) provide frameworks and benchmarks for program evaluation. This study should add to the existing knowledge in this respect, as this research attempts to build on what is already known regarding the frameworks and benchmarks for such programs. 


\section{BACKGROUND OF THE STUDY}

'Bilingual education programs can be defined as educational programs where two languages are used as a medium of instruction' (Nieto, 2000, p. 200). Some scholars interpret bilingual education as consisting of dual-language programs where the language of instruction is equally divided between two languages throughout the school day (Casanova \& Arias, 1993, p. 17). However, models vary and are interdependent on factors such as students, teachers, the local community, or the political system of a country.

The enrichment of bilingual education programs where English is used as a medium of instruction during a school day is in the focus of this study. A European example of such a dual-language focused approach is CLIL - Content and Language Integrated Learning. The European Commission has promoted this approach as a way of providing a bilingual education for all. CLIL refers to content teaching through any language; however, as Dalton Puffer (2011, p. 183) points out, the language used by the schools that implement it is mainly English. Therefore, she calls it CEIL - Contentand-English Integrated Learning. In CLIL, the teacher does not have to be a native speaker but needs to have a good command of the second/foreign language. The instruction in the second language usually takes up to $50 \%$ of teaching time in the curriculum (Cummins, 2013). The idea behind this is to allow children to develop their first language and add a second one early in their school education. This type of bilingualism can be described as 'additive bilingualism' and it is reported to have a positive influence on students' linguistic, cognitive, or academic growth (Cummins, 2006). This approach seems justified as by the age of four, children would have mastered the basic structures of their first language (Lightbown and Spada, 2006). Other views, such as Pavlenko's (2008), also regard bilingualism as extraordinarily advantageous for developing learners' linguistic skills and offering them alternative conceptualizations important for flexible and critical thinking. According to Baker (2001), bilingualism is the ability to use more than one language effectively. He describes it as balanced bilingualism.

In CLIL, the content is created in accordance with modern theories of how our brain learns (Coyle, Hood, and Marsh, 2010). The notion of content and language integrated learning is based on language acquisition rather than enforced learning (Mackenzie, 2012). Therefore, we can say that CLIL practice promotes a more natural use of language in various contexts, which also leads to awareness of and tolerance towards other cultures. 


\section{THE IMPLEMENTATION AND EVALUATION OF DUAL-LANGUAGE EDUCATION PROGRAMS}

What are the success factors of dual-language education programs? There are two criteria which help us answer this question: the measurement of implementation and evaluation procedures.

Lindholm-Leary (2001) states that dual-language programs are efficient in advancing language proficiency, academic achievement, and positive attitudes towards learning languages. What is more, Lindholm-Leary later confirmed that the evaluation of schools with bilingual education programs indicates relative success in promoting bilingual, biliterate, and multicultural competences (Lindholm-Leary \& Genesee, 2010). Having said that, we need to remember that students in these language programs do not represent a random sample of learners; often their parents directly decided that they should attend such a school. Therefore, this makes it more challenging to say whether the success of such schools is due to the program, the special characteristics of the students, the teachers, or maybe all of these factors. Let us, then, consider some of the above-mentioned factors. Language and culture are the main aspects of dual-language education to be taken into consideration when examining such programs. Learners' performance is another element that may be accessed both directly and indirectly: directly by evaluating language, literacy, and content knowledge; and indirectly by considering aspects connected to promotion, participation in contests, parent satisfaction, and the longterm effects of education on being a resourceful member of society (Brisk, 2010). One thing that can be said for certain is that students' achievements depend on the quality of bilingual programs. This may be assessed on the basis of their goals, leadership, school climate, curriculum, instruction, resources, assessment practices, preparation of personnel, and partnership with families (Brisk, 2010). Schools with successful bilingual programs demonstrate their accomplishments not only through test results but also by highlighting their students' attitudes, awards, and high attendance rates. However, one of the most important factors determining the success of a bilingual/multilingual education program is its curriculum. There is a great variety of programs available; some make a radical shift from one language to another, while others focus on the language as a subject throughout the curriculum as support to their use of it as a medium. The curricula cover the educational aims of the program, the time that the second language is introduced, the content, the subjects taught in L1 or L2, and the percentage of time spent on both. This study shows that the subjects usually taught in L2 are social sciences, geography, history, art, mathematics and physical education, but there is no predetermined syllabus in CLIL that any of the schools have to follow. Nevertheless, no matter what decisions schools make about the subjects taught in the additional language, the important 
factors here are progression and continuity (García, 2009). Deficiency of those two factors may lead to unsuccessful bilingual development in learners.

Assessing bilingual/multilingual education programs is a different matter. García (2009) notes that the success of a bilingual education program depends on the social situation rather than on the language of instruction. A number of studies have addressed the effectiveness of bilingual education programs in the past, whereas most of the studies make little reference to the characteristics of the program, the students, or the social context. Rather, they tend to show students' performance on standardized tests. Nevertheless, many researchers attempted to address this issue in the 1970s. Troike (1978) decided to conduct an in-depth case study. He analyzed 12 bilingual education programs within Spanish, Chinese, French, and Navajo populations. A few factors were evaluated, including English language competence, reading readiness, reading, writing, general outcomes, mathematics, and social studies. Performance in L1 was only measured in Spanish. This analysis supported the efficiency of bilingual programs. Many studies emerged afterwards (e.g. Dulay \& Burt, 1978). In the United States the discussion narrowed around the transition type of bilingual education. Baker and Kanter (1983) reviewed 261 studies and arrived at the conclusion that no particular education program should be legislated in the US and simply supported English-only and transitional bilingual education. However, their review was highly criticized by other researchers (Rolstad et al., 2005). Medina and Escamilla (1992) studied the effect maintenance bilingual programs have on the English language proficiency of Spanish speakers. However, all of the above studies at that time compared students in various bilingual education programs, but provided little detail about the school context. Ramírez's (1992) shows the effectiveness of long-term transitional bilingual programs, short-term transitional bilingual programs, and English-only programs. They incorporated students' outcomes in reading and mathematics, some evidence of instructional strategies, staff qualifications, and cooperation with parents. Many of the studies reflected upon the effectiveness of certain teaching strategies with bilingual students. The studies were conducted over an eight-year period and the outcomes were different for the three types of bilingual education. Nevertheless, they showed that when language minority students are given instruction in their mother tongue, this does not interfere with or delay their acquisition of English skills but has a positive impact on the content of subjects studied. By contrast, if the instruction is only in English students may fall behind in terms of the content. However, this study has also been criticized by Clay \& Cazden, 1992. Although much of the descriptive data was collected, most of the questions appear to be primarily predetermined not emergent. The qualitative information collected was used to document group comparability rather than to achieve an anthropological understanding of the phenomena observed. (Thomas, 1992) 
Recently, more research has been carried out in regard to students' success. The areas researched concerned the outcomes, the educational program characteristics in great detail, and the historical context of these programs. Lindholm-Leary (2001) conducted detailed data research from various studies of different types of duallanguage programs. The schools' contexts, programs, student outcomes, teachers' backgrounds and attitudes, as well as classroom activities were described in detail. As mentioned above, Lindholm-Leary concluded that dual-language programs are effective in promoting high academic achievement and positive attitudes to learning. Another large-scale research study was carried out by Thomas and Collier (2002), where students from different educational models were compared. During the study the backgrounds of students and teachers were investigated, and classroom observations were conducted. This study analyzed 210,054 students in five school districts. It focused on the performance of learners aged between 6 and 13 in mainstream education, ESL, developmental and two-way programs. Students performed above the national norms in only the 50-50 developmental programs and both forms of two-way programs. Students' success was measured by their achievements and contextual factors. Pérez (2004) studied two two-way programs in the San Antonio area. A historical and political context was presented together with other aspects of the program and students' performance. Nonetheless sociocultural integration is rarely measured by researchers as it is not considered a means to students' success.

The question that still remains, is: 'What tests or other sources of evidence are used to determine which form of bilingual education is successful (Torres-Guzmán et al., 2002), and how can this be implemented and evaluated effectively? Many of the studies show contradicting results. For example, Danoff et al. (1978) found mainstream education to be more effective than transitional bilingual education in the US. On the other hand, McConnell (1980) found US transitional bilingual education to be better than mainstreaming. Matthews (1979) found no differences between the two education types in the US (Baker, 2011). This is because the effectiveness of bilingual education can be viewed from different perspectives, and various aspects should be taken into account on different levels, ranging from the classroom to school level.

Success of bilingual education is generally measured by outcomes, and it is challenged by contextual factors (Brisk, 2010). There are hundreds of variables that affect program outcomes (Baker, 2011). Krashen (2004) believes that many individual studies inadequately focus on variables such as social class and initial language differences and ignore variables in design and program. Consequently, this study addressed the neglected issues of design and program in order to contribute to the existing knowledge in this respect. 
Brisk (2010), Mehisto (2012) and the Council of Europe (2010) provide frameworks and benchmarks for school evaluation, whose application should result in obtaining feedback on the school program. According to Mehisto, monitoring and evaluating give reference points and data, which can build confidence and constitute the key elements for program improvement. Data that are generated from several sources and databases, and crosschecked provide a solid basis for decision-making.

Schools that wish to incorporate a bilingual education program should pursue the following goals for bilingual learners, which address the outcomes by which a program is viewed as successful (Brisk, 2010, p. 97):

- Language proficiency to academic grade level.

- Sociocultural integration to their ethnic community and the society at large.

- Academic achievement, as defined by the school, for all students.

Other aspects of bilingual education that should be taken into consideration in order to improve bilingual development are the curriculum followed, pedagogies, individual learners, communities, and the balance between all of them (García, 2009).

All bilingual students should participate in a comprehensive and effective curriculum, meaning that:

- All content areas are covered.

- Content, language, and culture are integrated.

- Thinking and study skills are explicitly taught.

- Materials should be varied, high quality, interesting, and provided in the native language as well as English.

- Content and language assessment should be ongoing, authentic, and fair.

Language policies adopted by a school should be followed by all teachers in order to provide consistent language development. When planning a bilingual curriculum, language teaching, content and literacy should be integrated. Brisk (2010) confidently states that the mission of schools is to educate students so that they have choices when they graduate. Therefore, educating bilingual students should not merely teach students a second language or maintain their native language.

Monitoring and evaluation is, according to Mehisto (2012, pp. 38-39), a foundation for professional dialogue about bilingual education. Therefore, he proposes some reference points for consideration:

- Student learning of content, language, and related learning skills. 
- Stakeholder learning about the capacity to support the bilingual program.

- The ongoing development of effective bilingual learning environments.

- The achievement of the school strategic plan and subsequent work-plan targets.

- Program management/leadership.

All of the above areas should receive attention so that none of them is omitted and others overemphasized.

\section{THE STUDY}

\subsection{Research Method}

This research was grounded in Mixed Methods Research (MMR) traditions, where a combination of quantitative (QUAN) and qualitative (QUAL) approaches was applied. Such combination offers a better understanding of the research problem (Cresewell, Plano Clark, 2010). Qualitative data (in the forms of the interviews) provided a detailed understanding of a problem, while quantitative data (in the forms of the questionnaires) provided a more general understanding of a problem (Cresewell, Plano Clark, 2010). Integrating methodological approaches enhances the research design, as the strengths of one approach counterbalance the weaknesses of the other (Creswell and Plano Clark, 2011). MMR is the type of research design in which QUAN and QUAL approaches are used in the types of questions, research methods, data collection and analysis procedures. Therefore, deductive and inductive logic of inquiry should be applied and the research questions should be of primary importance.

A methodological triangulation was implemented in this study. It involved the use of qualitative and quantitative methods to conduct the research. The reason behind it was that this process allows to point to any contradictions and draw insights and interpretations. However, Patton (2002) cautions about a common misconception that the goal of triangulation is to arrive at consistency across data sources or approaches, and we need to keep that in mind.

As mentioned above, both strands intentionally interacted with one another during the course of the investigation. This convergent parallel design was implemented, as there was a need for a more thorough understanding of the topic. 


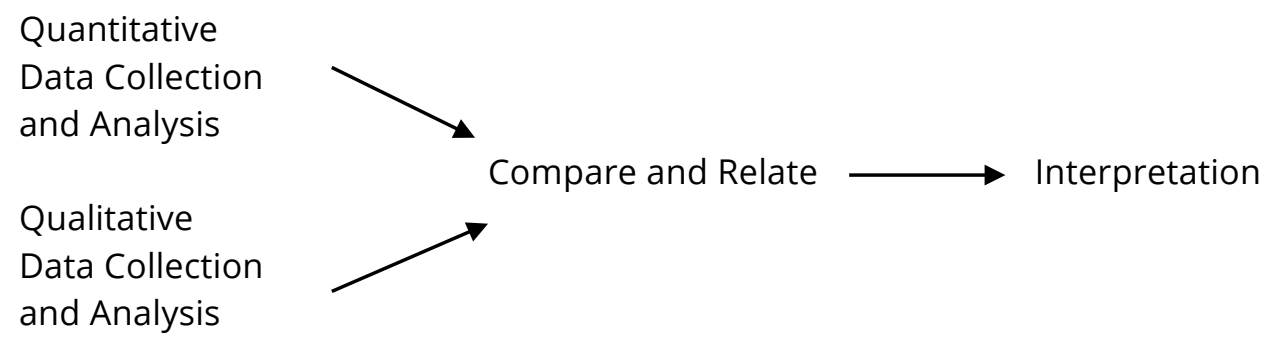

In this study equal priority was given to the two methods. The timing of the phases was concurrent. Both QUAL and QUAN methods were implemented during each phase of the study. The point of interface occurred during the design phase. The research design was fixed. The use of QUAL and QUAN methods was planned at the start of the study and later implemented. The results of the research were combined and interpreted together. The aim was to provide a holistic description of the individual context of the study (Teddlie \& Tashakkori, 2008). Mixed methods were appropriate in this study as the schools were chosen from various countries with their own dual-language education programs and the MMR allowed us to incorporate many diverse viewpoints (Cresewell and Plano Clark, 2010).

\subsubsection{Objectives}

Bearing in mind the above review of literature, this study puts forward the following main research question:

What are the internal assessment policies adopted by the schools for the evaluation of the effectiveness of their dual-focused programs?

In order to ensure that all of the above-mentioned factors contribute to successfully designed bilingual programs and their implementation, some of the questions used in our questionnaire were based on the frameworks and benchmarks indicated by Mehisto (2012, pp. 39-41). The aim was to cross-examine the schools' practices.

Thus the general objective was to identify the measures taken by the schools' principals when evaluating their dual-language programs.

The specific objectives were:

- To identify the frameworks and benchmarks adopted by the schools when evaluating the quality of their dual-language programs.

- To describe present education practices in terms of dual-language program evaluation in each of the participating schools. 
The aim of this study was, then, to identify frameworks and benchmarks as indicators of the measuring of the effectiveness of dual-language programs.

\subsection{Participants}

The schools that participated in the study were selected from Spain, the Netherlands, Italy and Poland. The selection was made in accordance with their geographical distribution criteria, which could give an idea of how bilingual programs are evaluated across Europe, and whether the benchmarks and frameworks identified by Mehisto (2012) are universal. The case selection was determined by the research purpose, questions, and theoretical context, but also by other restrictions such as accessibility, resources, and the time available (Rowley, 2002).

A spectrum of primary schools from Europe was needed for this study in order to answer the research questions and to reach valid conclusions. The study presents data concerning all grades of the primary schools involved.

The following schools were included in the study:

1. 'Schola Europea', a private primary school in Bergen, the Netherlands

2. 'Colegio Ramón Izquierdo', a Catholic public primary school in Badajoz, Spain

3. 'Scuola Sanzio', a public primary school in Trento, Italy

4. A public primary school in Wołów, Poland

5. 'Wroclaw International School', a private primary school in Wrocław, Poland A brief outline of the schools:

'Schola Europea', a private primary school in Bergen, the Netherlands.

Schola Europea is a school that prides itself for its multilingual environment. Lessons take place in English and are taught by native speakers, school prepares students for the European Baccalaureate. Students come from forty different countries. Pupils participate in a wide range of educational, cultural and social activities at school. The sciences and mathematics have an important role in the curriculum. However, the school also puts an emphasis on the creative arts, music, arts and drama. It also uses the latest developments in educational technology to develop ICT skills which prepare pupils for life beyond school, and some have the opportunity to participate in distant lessons with teachers across the continent. 
'Colegio Ramón Izquierdo', a Catholic public primary school in Badajoz, Spain.

The school follows the European Framework for CLIL Teacher Education, which provides a set of principles and ideas for designing curricula for professional teacher development in the area of Content and Language Integrated Learning (CLIL). Additionally, the framework serves as a tool for reflection. The Integrated Curriculum of Languages aims to develop multilingual and multicultural competence as elements that form the basis of communication in the European area, but also pursues the promotion of linguistic tolerance, as a condition for maintaining linguistic diversity.

The school is involved in the National Bilingual Education Program, and closely works on a government platform with other 25 schools participating in this project: http://programasbilingues.educarex.es/ All schools and teachers have been well equipped with modern technology tools, like interactive whiteboards, laptops, special tools online for the platform. All of which are in the school's daily use for the benefit of the students.

'Scuola Sanzio', a public primary school in Trento, Italy.

A state school located in the north of Italy. This school follows their local guidelines in regards to their curriculum. This school has designed their own guidelines for a CLIL curriculum. The pilot class finished the primary school and started the secondary in September 2013. This school's attention to foreign languages had been in response to social and cultural needs linked to the process of internationalisation and following the indications and guidelines expressed in numerous documents and studies of the European Union.

'Zespół Szkół Społecznych w Wołowie', a primary school in Wołów, Poland.

This is a public school, set up in 2001 and managed by an association of parents and teachers. Children can start their education in school's kindergarten and then continue it for the next six years in the primary school, later three years in the lowersecondary school and then three more years in the secondary sector. Parents pay the tuition fee for the association, though it is not very high. Children's day is filled with lessons and extra-curricular activities from 8.00 a.m. until 4.00 p.m. Pupils study according to the Polish national curriculum and take national examinations. The school cooperates with other educational institutions in Poland in their region as well as with the schools abroad to sustain a high standard of language and multicultural education. 
'Wroclaw International School', a private primary school in Wrocław, Poland.

Wroclaw International School is a private school for Polish and also foreign pupils living in Wrocław, Poland. It is an IB World School. It aims to foster international mindedness, supporting active participation in community life. This school has a dedicated, 'international' team of teaching and non-teaching staff who are committed to deliver a dynamic curriculum.

\subsection{Procedure}

The investigation was carried out within a pre-planned schedule. Data collection was done through questionnaires designed to evaluate each school's internal procedures in terms of the implementation and evaluation of their dual-language programs. The same procedure was followed for the five participating schools. The questionnaires were forwarded to the schools and filled in by the school principles or the bilingual program coordinators. At the same time, a series of interviews were conducted. The interviews were more informal, but also with pre-set questions that helped to structure it. However, the interviewer also asked additional questions based on the answers that the interviewees gave.

\subsection{Data analysis}

The most challenging stage in the mixed research process is analyzing data. Johnson, Onwuegbuzie and Turner (2007) indicate that decisions about the mixed analysis of a study can be made a priori, a posteriori, or iteratively. In this study, a priori decisions were made.

This study involved deductive and inductive logic of inquiry. Deductive reasoning was used at the beginning of the study to make certain predictions about the data needed to match the frameworks and benchmarks suggested by the experts. The premise in the deductive reasoning was the assumption that all of the schools use certain tools to measure the effectiveness of their bilingual education programs. Hence, there was a certain set of data gathered from the available literature and sources and used to deduce some new facts, in other words, to reach a logically certain conclusion. Inductive reasoning was used to piece together all of the data in a search for a common pattern and generalization. The deductive-inductive logic of inquiry allows the researcher to move from hypotheses to observations and then back to implications, backwards and forwards; it was found appropriate for the purposes of this investigation. 
The methodological triangulation was used in this study. It involved the use of multiple quantitative and qualitative methods to conduct the research. When triangulation is the rationale for conducting the mixed analysis, as it is in this study, the researcher compares findings from the quantitative data with the qualitative results. In view of the above, in this study, when the results from the questionnaires, and interviews were compared and similar results were found, then validity was established. However, Patton (2002) cautions against a common misconception that the goal of triangulation is to arrive at consistency across data sources or approaches. In Patton's view, these inconsistencies should not be seen as weakening the evidence, but should be viewed as an opportunity to uncover deeper meaning in the data. This is the approach this study aimed to take. Those contradicting findings and controversies or crises, as Onwuegbuzie and Collins (2007, p. 304) call them, happen due to certain barriers, identified by Mingers (2001) as philosophical, cultural, cognitive and practical. In this study practical and cultural barriers were present. Practical, as it was not easy to get to all of the schools and their principals and to conduct the research in a similar manner, due to the lack of time or cultural differences. Some of the principals who filled in the questionnaire did it on their own in a quiet place, others in the lesson, while talking to the researcher and the children. Therefore, we can say that sometimes more evidence was collected than expected and sometimes precisely what was needed. While analysing the data in this study the information from the interviews was used to provide additional evidence while describing the tables, which contain the information from the questionnaires.

The questionnaire consisted of a set of open and closed questions that had been sent for validation to a number of experts in the field of dual-language education. The questions had been worded to provide the information needed by the researcher. The responses from the questionnaires (open and closed questions) were transferred onto a spreadsheet and presented in a form of tables as shown below in the Results section. The answers and the findings can be found in tables 1 to 6 below.

\section{RESULTS}

\subsection{Results}

The questions in our questionnaire addressed the following areas:

1. Is the bilingual curriculum integrated into the whole school curriculum?

2. In what ways is the academic achievement measured? 
3. Is language and content assessed and discussed in all classes?

4. What is the percentage of the time spent on L1 and L2?

5. What types of qualifications are required from the $L 2$ teachers?

6. In what ways is the effectiveness of the curriculum measured?

7. Are any of the following frameworks / benchmarks followed by the school in order to obtain feedback on the bilingual program?

The school principals surveyed declare adopting dual-language curricula and English as the language of instruction. In Bergen the proportion is about 60/40 throughout the school years, but most subjects are also studied in the L1. In Trento bilingual classes start in year 1 and involve 20 hours out of 30, while eight subjects are entirely taught in L2; only Italian, history, and religion are delivered in L1. In Wroclaw, the primary grades have two 45-minute Polish lessons. In the middle school the students have the option of Language B, which is either French or Polish. As for Wołów, there is no set proportion between L1 and L2 - parts of lessons are taught in $L 2$, usually mathematics, biology or PE. The school declares that it increases the time spent on L2 as pupils' L2 competence improves.
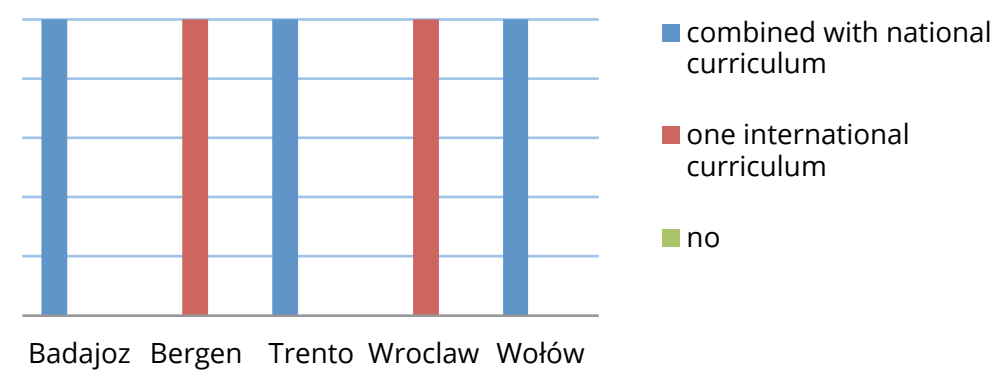

Table 1. Is the bilingual curriculum integrated into the whole school curriculum?

The results show some discrepancies between the schools in terms of measuring students' academic achievement. Badajoz declares using formative and summative assessment. Bergen advocates using a combination of skills, knowledge and analysis which is reflected in a range of marks with summative and formative assessment. Trento uses standardized and not standardized works (oral and written). Wrocław has its own policy and implements a variety of measurement tools and tasks depending on the stage of the learning activity. Diagnostic, formative or summative assessments are taken. Set criterion is set, however students are actively involved in setting assessment criteria and benchmarks. Wołów is relatively new to bilingual 
education programs and uses their own mock exams to test students' knowledge of English as well as end of module tests.
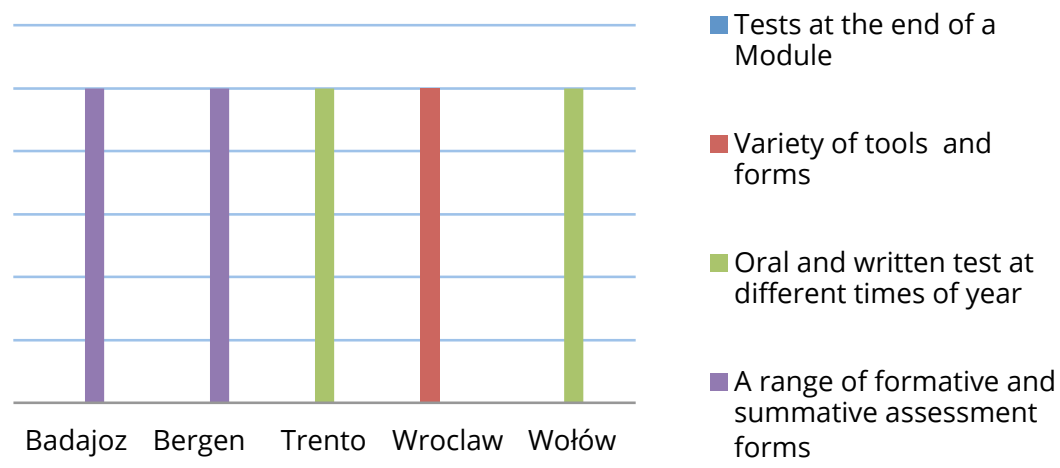

Table 2. In what ways is the academic achievement measured?

Badajoz stresses the importance of using bilingual science books, which follow the same topics in Spanish and in English. Bergen states that language is assessed in language classes but not necessarily in other subject classes. Trento maintains the assessment of language and content in all bilingual classes. The teachers in Trento use Assessment for Learning as their fundamental tool. Wrocław stresses the importance of every teacher to be responsible for the teaching of language. In Wołów, the situation depends on the subject of a particular class. As they stated, there might not be time or need for both.

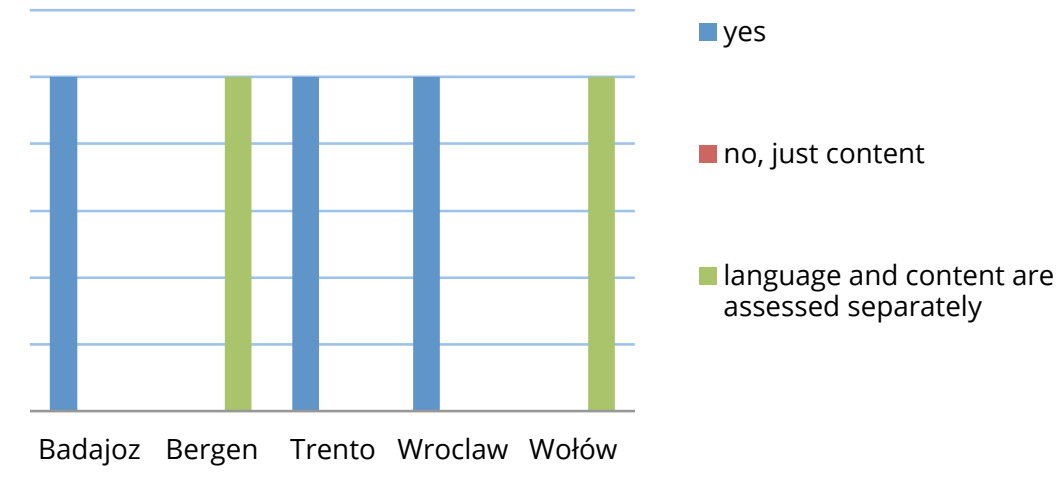

Table 3. Is language and content assessed and discussed in all classes?

The results show different principles in terms of the use of L1 in the lessons. In Wołów, Badajoz, and Trento the schools are monolingual and the teachers speak the same mother tongue as the children, so any uncertainties in meaning can be clarified instantly in their L1. By contrast, Wrocław and Bergen are comprised of 
international students and teachers and translanguaging between the teachers and students is often not possible.
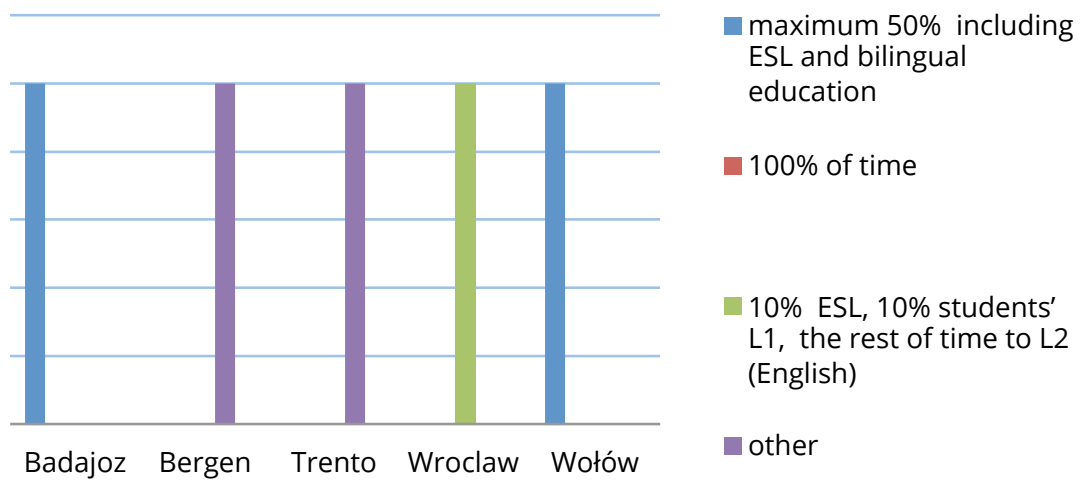

Table 4. What is the percentage of time spent on L1 and L2?

Teachers' qualifications seem to be a greater issue in general. At schools where native speakers of English are employed, the requirement is to have a degree in a subject (Bergen, the Netherlands; Wrocław, Poland; Trento, Italy). A different requirement applies to teachers who are subject teachers and would like to teach the content of their subject through English. They are required to have a certificate relating to language proficiency, usually the Cambridge English First Certificate (FCE). Some schools (Wołów, Poland; Trento, Italy; Badajoz, Spain) admit employing teachers without language qualifications as they lack teachers to conduct lessons in bilingual classes and simply involve subject teachers who have a good command of English.

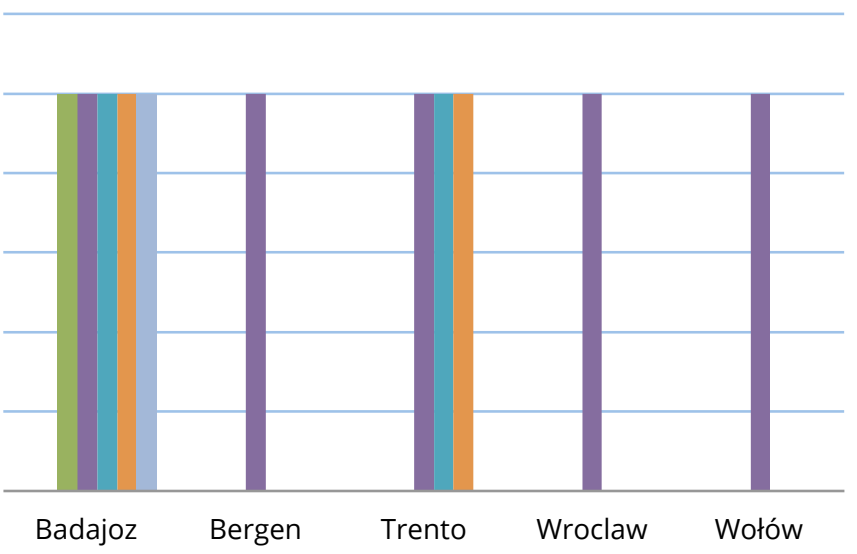

BA in integrated education

BA in bilingual education

MA in bilingual education

BA or MA in a specific subject teaching

- Cambridge TKT: CLIL test

Table 5. What type of qualifications are required from the $L 2$ teachers? 
The school in Badajoz measures the effectiveness of their curriculum by conducting students' tests. It is easy since the same program is used in Spanish and in English. In Bergen the effectiveness is measured by national inspectors responsible for subjects. The baccalaureate exams are centrally set and carefully monitored. There is quality control throughout and a system of checks and balances. Trento follows its own bilingual curriculum. Students have national tests every year, called Istituto Nazionale per la VALutazione del Sistema dell'Istruzione (INVaISI). In Wrocław there is a requirement of the IBO that each school authorized to offer one or more of their programmes have a 5-year evaluation. Yearly reflection and revision sessions on the programme of inquiry are also undertaken. Wołów declares to have parts of regular assessment (with main focus on oral assessment) conducted in English.

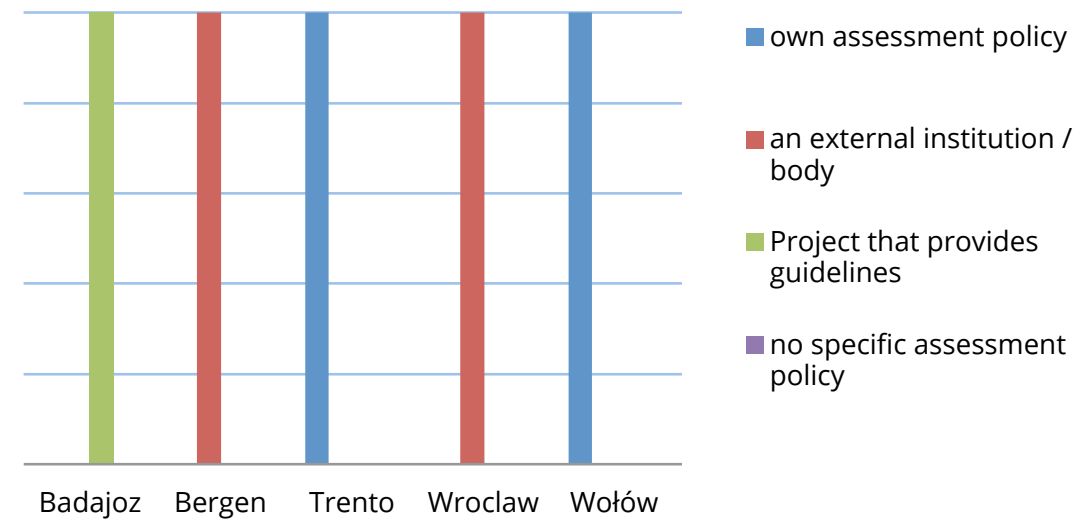

Table 6. In what ways is the effectiveness of the curriculum measured?

All of the schools confirm doing lesson observations. Most of the teachers are only observed by their supervisors, some of them do peer-observations additionally. Only Wrocław and Wołów conduct anonymous surveys among members of staff. Selfreflection and assessment frameworks, as well as one-to-one and group meetings and correspondence with students, parents, and staff are declared by all of the schools. Only Wołów and Badajoz have database of student grades over several grades. Bergen was considering introducing such a database in their school. Curriculum expectations/goals/outcomes are maintained by all of the schools. 


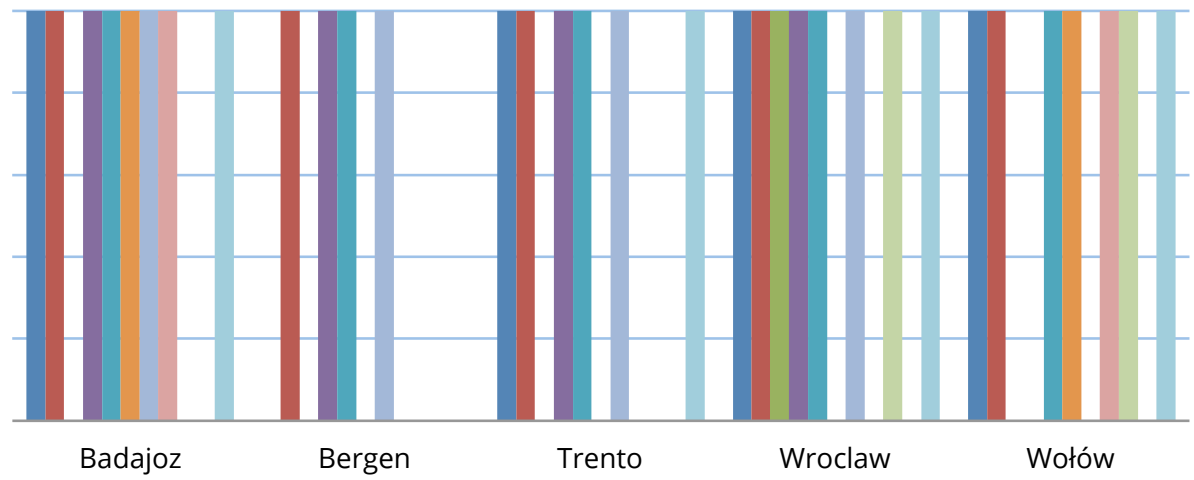

staff meetings (at least once a month)

lesson observations

anonymous surveys

self-reflection and assessment frameworks

one-to-one and group meetings and correspondence with students, parents, staff etc

database of student grades over several years

curriculum expectations/goals/outcomes set

key performance indicators (KPI)

league labels

Table 7. Are any of the following frameworks / benchmarks followed by the school in order to obtain feedback on the bilingual program?

Additional information that was gathered from the interviews provides a greater picture of assessment at the schools participating in this study. In most of the schools students' performance is recorded via standardized tests at the end of the unit or school term (Badajoz, Spain; Wołów, Poland). The information collected during the interviews showed that some of the teachers, especially in public schools (Badajoz, Spain; Wołów, Poland), know very little of what formative assessment is and how it should be used in a bilingual classroom; indeed, the idea seemed vague and unproductive to them. Using formative assessment in an L2 seemed daunting, especially since it was not part of the overall end-of-term grade. However, the schools which have more experience in providing bilingual education programs tend 
to shift towards more formative assessment, where learners' performance is measured by real-life tasks, reflecting the instructional aims of the curriculum (Bergen, the Netherlands; Wrocław, Poland; Trento, Italy). Nevertheless, there seems to be a discrepancy between assessing language and content, and in the schools where students spend more time in classes working in their $\mathrm{L} 2$ there seems to be a greater focus on content (Wrocław, Poland), while in schools where there is less time devoted to L2 there is a tendency to focus on language in assessment (Wołów, Poland; Badajoz, Spain). One of the schools, the public primary school in Trento, Italy, included "Assessment for Learning" as part of their daily practice.

Evaluation of the schools' curricula shows significant differences in all of them. The research showed that some school principals (Badajoz, Spain; Wołów, Poland) tend to depend on student assessment (mid-term and end-of-year tests) as means of their program assessment. The evaluation procedures were neither transparent to the staff, nor negotiated with them. Some schools had no bilingual curriculum outcomes prescribed (Wołów, Poland), others used a curriculum designed and accredited by their local government (Trento, Italy; Badajoz, Spain), while others followed an international curriculum that guides them towards a certain outcome and requires certain procedures, audits, and inspections (Bergen, the Netherlands; Wrocław, Poland).

As shown above, it seems that schools' own assessment policies can be successful (Trento, Italy) when they involve self-reflection and work plan targets apart from the school's strategic plan. The school's own strategic plan that does not include the above elements might not be as successful as the school's principal would like it to be (Wołów, Poland). As already mentioned in this article, no matter which subjects are chosen to be taught in the additional language, the important factors here are progression and continuity (García, 2009).

\section{Discussion}

Currently many of the education programs in the world are either designed for social elites or for disadvantaged immigrants who are placed in transitional bilingual education programs. Hence, the aim of this study was to include state schools as well as private ones for comparison. This study gathered information that suggests that schools, where an external body provides the guidelines and benchmarks for assessment (e.g. Wroclaw, Bergen), are more confident in running their programs and make the improvements more visible in their programs than those that create their own evaluation criteria, as they are not experts in designing bilingual education programs. Of course, there are some general curricular guidelines in Europe on how to implement CLIL - for example, www.clilcompendium.com or www.clilconsortium. 
jyu.fi (access date Dec. 2014) to name only two - but they are very broad and need to be adapted to each school's individual context. This shows the necessity for local councils or governments to produce appropriate guidelines to be followed by schools willing to introduce bilingual education programs. In the Netherlands, a national accreditation system for CLIL schools has been established (www.europeesplatform.nl, access date Dec. 2014). In Poland there are no such guidelines. Trento is an example of good practice. It is located in a region with an independent education system, where schools follow the PAT curriculum (Autonomous Province of Trento), which is an adaptation of the national curriculum and reflects this region's political, historical, and geographical reality. In Spain, there have been numerous projects conducted in respect to CLIL implementation that provide guidelines for schools (Escobar Urmeneta, 2010; the British Council and the Ministry of Education, 2010). There are many uncertainties expressed by schools starting to implement bilingual education programs. Some schools (for example, Wołów, Poland) have expressed numerous doubts about the subjects that need to be taught in L2, the number of hours spent on L2, and which extra-curricular activities should be pursued, to name a few, as there are no guidelines available. In view of such obstacles, the evaluation of lessons (learning and teaching), the program's goals, and/or outcomes are obviously overlooked, if not neglected altogether.

Currently, a tendency that can be observed across Europe is for subject teachers to attend English language courses in order to improve their English language skills. However, as recorded in this study, not only teachers' language skills need improvement, but also the methodology of English language teaching and the understanding of dual-language education as a whole. This study indicates the need for subject teachers' to attend further training. This demand is especially strong among those teachers who were told to teach their subject in L2 without prior training (Wołów, Poland) or with little training (Badajoz, Spain). It is hard to become competent professionals without training (Larrea, Raigón and Gómez, 2012, p. 12).

This study shows that teachers who have some previous theoretical training, know the theory of dual-language curriculum and teaching well, but do not always apply it in their lessons. It seems that this type of training is beneficial in terms of their understanding of theory but not in changing teachers' habits in terms of lesson planning and conducting the lessons. In view of the above, it can be stated that bilingual schools need a lot of external support in terms of in-house or school-based training, designing materials, planning lessons, conducting assessment, as well as peer and external lesson observations and evaluation. In schools that have just started applying their bilingual education programs there is a greater need for 
teacher training than in those which have been established for a longer period of time where teachers are more experienced.

However, there is rather little support offered towards the school principals and the administrative staff in reference to the management of the internal procedures of evaluating dual-language programs that would help them systematize and improve their programs. Montecel and Cortez (2002) note that there must be professional development for administrators and teachers with the focus on assessment and the interpretation of assessment data. This could take the form of a formal training later directed towards more independent work by the schools on their own policies, as in Trento. Schools in the same district could subsequently be joined together and share, discuss and evaluate their programs together. Effective schools use assessment benchmarks aligned with their school's vision and goals, curriculum and related standards (Lindholm-Leary \& Molina, 2000).

Therefore, we can say that there is an urgent need for effective and real institutional support. There should be more assistance provided for the schools wishing to implement a bilingual curriculum in the form of practical publications/guides, as well as personal support from teacher trainers and curriculum developers. Schools need modern and easy mechanisms to implement tools to monitor and evaluate their programs. This will help them constitute the key elements for improvement and evolvement. Data that would then be generated from several sources, and databases could provide a solid basis for decision-making, as Mehisto (2012) suggests.

\section{About the authors}

Barbara Muszyńska, MD, is a lecturer at the Faculty of Education at University of Lower Silesia in Wroclaw, Poland. She is the head of the EFL and EAP programme at the Faculty of Education. She is responsible for the quality of the teaching programme. She also teaches English, CLIL and Methodology of Teaching English to Younger Learners in Teacher Education. In 2012 she started her PhD program at the University of Cordoba in Spain. Her research was done in chosen schools in Europe and concerned the tools used for evaluation of bilingual education programs.

$M^{a}$ Elena Gómez Parra, PhD, is Lecturer of English at the Department of English and German Philology at the University of Córdoba, Spain. She also holds an MD in Distance Education. Her research lines focus on bilingual and intercultural education. She teaches CLIL and English in Teacher Education (English) and 
Intercultural Communication and Academic Writing at Master's Level. She has enjoyed some research stays in the USA (Univ. of Berkeley; Bowdoin College) and the UK (University of Manchester). She has coordinated the English and German sections in the Language Centre of the University of Córdoba (2000-2006) and she has been the Ass. Dean for International Affairs at the Faculty of Education (20062014).

\section{Article history}

Paper received: 23rd March 2015

Paper received in revised form and accepted for publication: 28th September 2015

\section{REFERENCES}

Baker, C. (2011). Foundations of bilingual education and bilingualism, 5th edition. Clevedon: Multilingual Matters.

Baker, C. (2001). Foundations of bilingual education and bilingualism, 3rd edition. Multilingual Matters, Clevedon.

Baker, K. A., \& de Kanter, A. A. (1983). Bilingual education: A reappraisal of federal policy. Lexington, MA: Lexington Books.

Brisk, E. (2010). Bilingual Education. From compensatory to quality schooling. Routledge: London and New York.

Casanova, U., Arias, M. B. (1993). Contextualizing bilingual education. In M. B. Arias \& U. Casanova (Eds.), Bilingual education: Politics, practice and research, (pp. 1-35). Chicago: University of Chicago Press.

Cazabon, M., Lambert, W. E., \& Hall, G. (1993). Two-way bilingual education: A progress report on the Amigos Program, Research Report No. 7. University of California, Santa Cruz, CA: The National Center for Research on Cultural Diversity and Second Language Learning.

Clay, M., Cazden, C. (1992) A Vygotskian interpretation of reading recovery. In Cazden, C. (Ed.), Whole language plus: Essays on literacy in the US and NZ. New York: Teachers College Press.

Council of Europe. (2010). Guide for the Development and the Implementation of curricula for plurilingual and intercultural education. <https://www.coe.int/t/dg4/linguistic/Source/ Source2010_ForumGeneva/GuideEPI2010_EN.pdf> [10/10/2013] 
Coyle, D., Hood, P., \& Marsh, D. (2010). CLIL: Content and language integrated learning. Cambridge: Cambridge University Press.

Creswell, J. W., \& Plano Clark, V. L. (2010). Designing and conducting mixed methods research, $2^{\text {nd }}$ edition. London: Sage Publications.

Creswell, J. W., Klassen, A. C., Plano Clark, V. L., \& Smith, K. C. for the Office of Behavioral and Social Sciences Research. (2011). Best practices for mixed methods research in the health sciences. Washington, DC: National Institutes of Health. <http://obssr.od.nih.gov/mixed_ methods_research> [10/12/2014]

Cummins, J. (2006). Language, power and pedagogy. Bilingual children in the crossfire. Great Britain: Cambarian printers Ltd.

Cummins, J. (2013). Content and language integrated learning (CLIL): Research and its classroom implications. Padres y Maestros, 349, 6-10.

Dalton-Puffer, C. (2011). Content and language integrated learning: from practice to principles. Annual Review of Applied Linguistics, 31, 182-204.

Danoff, M., Coles, G., McLaughlin, D., \& Reynolds, D. (1978). Evaluation of the impact of ESEA Title VI1 Spanish/English bilingual education programs (vols. 1-3). Palo Alto, CA: American Institutes for Research.

Dulay, H. C., \& Burt, M. K. (1978). Some remarks on creativity in language acquisition. In W. C. Ritchie (Ed.), Second language acquisition research: Issues and implications (pp. 65-89). New York: Academic Press.

Escobar Urmeneta, C. (2010). Pre-service CLIL Teacher-Education in Catalonia: Expert and novice practitioners teaching and reflecting together In: D. Lasagabaster \& Y. Ruiz de Zarobe (Eds.), CLIL in Spain: Implementation, results and teacher training (pp. 189-218). Newcastle, UK: Cambridge Scholars Publishing.

García, O. (2009). Bilingual education in the $21^{\text {st }}$ century. A global perspective. Oxford: WileyBlackwell.

Genesee, F., Geva, E., Dressler, C., \& Kamil, M. (2005). Synthesis: Cross-linguistic relationships, Chapter 6. In D. August \& T. Shanahan (Eds.), Developing literacy in second language learners. Report of the National Literacy Panel on Minority-Language Children and Youth (pp. 153-174). Mahwah, NJ: Lawrence Erlbaum.

Howard, J. S., Sparkman, C. R., Cohen, H. G., Green, G., \& Stanislaw, H. (2005). A comparison of intensive behavior analytic and eclectic treatments for young children with autism. Research in Developmental Disabilities, 26, 359-383. 
Johnson, R., Onwuegbuzie, A., Turner, L. (2007). Toward a definition of mixed methods research. Journal of Mixed Methods Research, 1(2), 112-133.

Krashen, S. (2004). The Power of reading. Portsmouth, NH: Heinemann.

Larrea Espinar, A.M., Raigón Rodríguez, A.R. \& Gómez Parra, M.E. (2012). ICT for Intercultural Competence Development. Píxel Bit: Revista de medios y educación, 40, 115-124. <http:// www.redalyc.org/pdf/368/36823229009.pdf> [11/02/2014]

Lightbown, P., \& Spada N. (2006). How languages are learned, $3^{\text {rd }}$ edition. China: Oxford University Press.

Lindholm-Leary, K. J. (2005). Review of research and best practices on effective features of dual language education programs. San Hose State University. <http://www.lindholmleary.com/resources/review_research.pdf > [05/05/2014].

Lindholm-Leary, K. J. (2001). Dual language education. Clevedon: Multilingual Matters.

Lindholm, K.J., \& Molina, R. (2000). Two-way bilingual education: The power of two languages in promoting educational success. In J.V. Tinajero \& R.A. De Villar (Eds.), The power of two languages 2000: Effective dual-language use across the curriculum (pp. 163-174). New York: McGraw Hill.

Lindholm-Leary, K. J., Genesee, F. (2010). Alternative Educational Programs for English Learners. In California Department of Education (Eds.), Improving Education Programs for English Learners: Research-Based Approaches (pp. 323-382). Sacramento: CDE Press.

Mackenzie, A. (2012) How should CLIL work in practice? <http://www.onestopenglish.com> [10/01/2014]

Medina, M. Jr., Escamilla, K. (1992). English acquisition by fluent- and limited-Spanishproficient Mexican Americans in a 3-year maintenance bilingual program. Hispanic Journal of Behavioural sciences, 14, 252-267.

McConnell, B. B. (1980). Effectiveness of individualized bilingual instruction for migrant students. Unpublished doctoral dissertation, Washington State University.

Mehisto, P. (2012). Excellence in bilingual education: A guide for school principals. Cambridge: Cambridge University Press.

Mingers, J. (2001). Combining IS research methods: Towards a pluralist methodology. Information Systems Research, 12, 240-259.

Montecel, M.R., \& Cortez, J.D. (2002). Successful bilingual education programs: Development and the dissemination of criteria to identify promising and exemplary practices in bilingual education at the national level. Bilingual Research Journal 26(1), 1-21. 
Nieto, S. (2000). Affirming diversity: The sociopolitical context of multicultural education. New York: Longman.

Onwuegbuzie, A.J., \& Collins, K. (2007). A typology of Mixed Methods Sampling Designs in Social Science Research. The Qualitative Report 12(2), 281-316, <http://www.nova.edu/ss ss/QR/QR12-2/onwuegbuzie2.pdf> [04/06/2014].

Patton, M. (2002). Qualitative research and evaluation methods, $3^{\text {rd }}$ edition. Thousand Oaks, CA: Sage Publications.

Pavlenko, A., \& Jarvis, S. (2008). Crosslinguistic influence in language and cognition. New York and London: Routledge.

Pena, C., Porto, M. D. (2008). Teacher beliefs in a CLIL education project. Porta Linguarum 10, 151-161, <http://www.ugr.es/ portalin/articulos/PL_numero10/11\%20Carmen\%20Pena.p $d f>[04 / 12 / 2013]$.

Pérez, B. (2004). Becoming biliterate: A study of two-way bilingual immersion education. Mahwah, $\mathrm{NJ}$ : Lawrence Erlbaum Associates.

Ramírez, J. D. (1992). Executive summary. Bilingual research Journal, 16, 1-62.

Rolstad, K., Mahoney, K., \& Glass, G. V. (2005). The big picture: A meta-analysis of program effectiveness Research on English language learners. Educational Policy, 19(4), 572-594.

Rowley, J. (2002). Information marketing in a digital world. Library Hi-Tech, 20(3), 352-358.

Tashakkori, A., \& Teddlie, Ch. (2008). Quality of inferences in mixed methods research. In Bergman, M. (Ed.) Advances in mixed methods research: Theories and applications. London, UK: Sage.

Thomas, W. P., \& Collier, V. P. (2002). A national study of school effectiveness for language minority students' long term academic achievement. Santa Cruz, CA: Canter for Research on Education, Diversity and Excellence.

Thomas, W. (1992). An Analysis of the Research Methodology of the Ramirez' Study. Bilingual Research Journal, 16(1-2), 213-246.

Torres-Guzmán, M. E., Abbate, J., Brisk, M. E., \& Minaya-Rowe, L. (2002). Defining and documenting success for bilingual learners: A collective case study. Bilingual Research Journal, 26(1), 23-43

Troike, R. C. (1978). Research evidence for the effectiveness of bilingual education. NABE Journal, 3(1), 13-24.

Van de Craen, P. (2009) Educating the Brain. In Desmond, K. (Ed.), Flanders Today <www.flan derstoday.eu/content/educating-better-brain> [05/12/ 2013] 